\title{
The Study of Bus Rapid Transit (BRT) System at University Road Peshawar, Pakistan
}

\author{
Ghulam Dastagir $^{1, \mathrm{a}}$, Rawid Khan ${ }^{1, \mathrm{~b}}$, Omar Shahid ${ }^{1, \mathrm{c}}$, Awal Mir ${ }^{1, \mathrm{~d}}$, M Faheem ${ }^{1, \mathrm{e}}$ \\ ${ }^{1}$ University of Engineering \& Technology Peshawar, Pakistan
}

\begin{abstract}
The paper is part of an ongoing research project on traffic management strategies for Peshawar Pakistan. A survey of all the existing public transport stops on University Road Peshawar conducted for identification of bus lane. Peak hour demand was calculated in terms of actual Passengers per hour per direction (Pphpd)along the entire corridor which acts a warrant test for the provision of a separate lane for public transport vehicles in Bus Rapid Transit (BRT) System. Saturation Levelsand Dwell Times (sec)at every stop both for busses and for wagons usingfrequency, clearance time, amount of boarding and alighting passengers and journey time of existing public transport system were analyzed.From data analysis, theSaturation Levels and Dwell Times at every stop were found higher than the recommended values mainly because of the obstruction due to private vehicles in front of public transport vehicles, a comparatively high percentage of private vehicles with respect to public transport vehicles and the prolong stay of drivers atbus stops. The Saturation Levels and Dwell Times (sec) for the proposed BRT system was re-analyzed. Finally, result of the proposed BRT system was incorporated in S-Paramics software to develop a public transport model.
\end{abstract}

Keywords: Peak hour Demand, Warrant test, SaturationLevels, Dwell Times.

\section{Introduction}

An efficient and cost effective public transport system is essential for daily mobility of people. For many cities where effective public transport has been forgone, leaving mobility needs exclusively in the hands of private vehicles and un-coordinated Para transit operators. BRT system is increasingly recognized as amongst the most effective solutions in providing high quality transit services on a costeffective basis to urban areas both in the developed and developing world. BRT is high-quality, customer-orientated transit that delivers fast, comfortable and cost effective urban mobility[1-3].

BRT systems are generally built on corridors where mixed traffic congestion is already a problem, or where congestion is likely to occur in the near future [4]. There is bus/wagonpublic transport system operating mixed with private vehicles has not only resulted un-necessarily increased travel time but also have decreased the capacity of roads. The corridor of University Road Peshawarwas selected in this research because of some specific problems observed such as:Traffic congestion at corridor, high waiting times at stop, non-punctuality of public transport vehicles, traveling at speed less than the design speed, increased travel time, interference of private vehicles. The selected corridor consists of six lanes with three lanes in each direction.

BRT system at a corridor may be achieved by considering improvements to the existing infrastructure, vehicles and by proper scheduling [5].

Improvements in Existing Infrastructure:Such as provision of segregated right of way that is without interference from other modes of traffic in order to encourage modal shifts from private vehicles to public transport to overcome overall congestion.Provision of enhanced stations that are convenient, comfortable, secure and weather protected so that more passengers are attracted towards the stations in spite of locations other than the stations.

Improvements in Vehicles:Reduce operating costs. (Old tech vehicles consumes more fuel than new tech vehicles)

Improve riding quality. (New tech vehicles can minimize the discomfort of slowing and stopping vehicles)

Increase capacity. (By use of standard sized or articulated type buses)

Proper Scheduling:This includes for example the frequency of the service that should minimize the waiting times for the passengers standing over the stop. The service speed of the vehicles so that to minimize travel times; and the capacity to fulfill the existing as well as expected passenger demand.

The objective of this research was to investigate the current and projected passenger demand on University Road by use of innovative infrastructure and proper scheduling to provide a service that is faster and more frequent than the existing bus/wagon operations. 


\section{Methodology}

Traffic surveyfor identification of existing public transport stops at University Road was conductedfrom Gora Qabristan towards Phase-3 Intersection(Figure 01).Traffic demand analysis that serves as the base for the planning design workwas performed.Demand analysiswas used to determine the solution for various demands over the corridor. It acts as a warrant test for the provision of a separate lane for public transport vehicles in BRT System. Demandwas calculated in terms of Passengers per hour per direction, Pphpd (Actual) along the entire corridor. At every stopping bay, buses and wagonspassengers were counted for 15 minutes in peak hours on three days of the week i.e. Monday to Wednesday as one hour interval would provide less insight into peak and non-peak conditions. Thus 15 minutes interval provides a reasonably fine level of peak identification. Pphpdat every stop for buses and wagons were estimated using interpolation and by summation of all the Pphpdat every stop, Pphpd (A) for the entire corridor was calculatedfor the specified day. Instead of peak one value of the three days, An average value of peak hour demand was taken for further analysis and design, so that the profitability of the system do not suffer.

Pphpd (A) = Pphpd (Buses) + Pphpd (Wagons)

Sample Table for data collection

\begin{tabular}{|c|c|c|c|c|c|c|c|}
\hline \multicolumn{8}{|c|}{ Data for Passengers per hour per direction (Actual) (For Peak Hours Scheduling) } \\
\hline \multirow[b]{2}{*}{ Day } & \multirow{2}{*}{$\begin{array}{l}\text { Stop } \\
\text { name }\end{array}$} & \multirow[b]{2}{*}{ Direction } & \multicolumn{2}{|c|}{ Time (15 minutes) } & \multirow{2}{*}{$\begin{array}{c}\text { Total no of } \\
\text { passengers on } \\
\text { stop }\end{array}$} & \multirow{2}{*}{$\begin{array}{c}\begin{array}{c}\text { Bus } \\
\text { passengers }\end{array} \\
\begin{array}{c}\text { No of } \\
\text { passengers over } \\
\text { stop }\end{array} \\
\end{array}$} & \multirow{2}{*}{$\begin{array}{c}\text { Wagon } \\
\text { passengers }\end{array}$} \\
\hline & & & Start time & End time & & & \\
\hline Mon & & Gora & & & & & \\
\hline Tues & & Qabristan to & & & & & \\
\hline Wed & & Phase-3 & & & & & \\
\hline \multicolumn{8}{|c|}{ Average No of Passengers over stop from Mon-Wed Till 15 minutes } \\
\hline Avera & & engers Per & & & & & \\
\hline
\end{tabular}

Direction indicatesthe travel from Gora Qabristan towards Phase-3 Intersection.

Table-01: Typical solutions for different demand levels (BRT Planning Guide 2007)

\begin{tabular}{|l|l|}
\hline \multicolumn{1}{|c|}{$\begin{array}{c}\text { Transit passengers per } \\
\text { hour per direction }\end{array}$} & \multicolumn{1}{c|}{ Type of BRT Solution } \\
\hline Less than 2000 & $\begin{array}{l}\text { Simple bus priority, normally without physical segregation, possible } \\
\text { part-time bus lane }\end{array}$ \\
\hline 2000 to 8000 & Segregated bus way, single lane, single stopping bay per station \\
\hline $8000-13000$ & Convoy system (Without Passing lane) \\
\hline Greater than 13000 & Multiple stopping bay with Passing lanes \\
\hline
\end{tabular}

In order to add the effect of modal shift, private vehicles (Cars, Motor cycles \& Taxies) were counted on the selected corridor. The purpose of this counting was to provide an early indication of how many passengers could potentially switch from private transport to public transport. The experience of other cities lends some basis for prediction. In most reasonably well designed systems, around 5 to 20 percent of the motorists switch from private vehicles to BRT along a given corridor [1, 7-9].

Pphpd (AM) including Modal shift $=$ Pphpd $($ Buses $)+$ Pphpd $($ Wagons $)+$ Modal Shift

Table-02: Projected modal shift impact [1]

\begin{tabular}{|l|c|}
\hline \multicolumn{1}{|c|}{ Type of BRT Corridor } & $\begin{array}{c}\text { Projected Modal Shift Impact from } \\
\text { private vehicles }\end{array}$ \\
\hline Little congestion, buses > 30\% of the vehicle fleet & $5 \%$ \\
\hline Some congestion, buses around 25\% of vehicle fleet & $10 \%$ \\
\hline Many links congested, buses around 15\% of vehicle fleet & $15 \%$ \\
\hline Very congested, few buses on the corridor & $20 \%$ \\
\hline
\end{tabular}


The analysis of existing saturation level (XE) was done at every stop both for busses and wagons. The saturation level of a station refers to the percentage of the time that a stopping bay is occupied by vehicles. According to BRT Planning Guide, the equation for saturation level is:

$$
X=[(\text { tc } x \text { F })+(P b x \text { Tb })+(P a \times T a)] / 3600
$$

$\mathrm{X}=$ Saturation level at stop

tc $=$ Clearance time $($ Seconds/vehicle $)$

$\mathrm{F}=$ Vehicle frequency (Vehicle/hour)

$\mathrm{Pb}=$ Number of boarding passengers/hour

$\mathrm{Pa}=$ Number of alighting passengers/hour

$\mathrm{Tb}=$ Average boarding time per passenger (Seconds/passenger)

$\mathrm{Ta}=$ Average alighting time per passenger (Seconds/passenger)

For calculating existing saturation level (XE) at every stop, data was collected from Monday to Wednesday in the direction towards Phase-3 Intersection. Arrival and departure time noted for every bus and counted the number of buses and boarding \& alighting passengers until 15 minutes. Through interpolation, number of buses and boarding \& alighting passengers per hour were estimated. The time per passenger was calculated by taking difference between the arrival and departure time of bus and divide it by the sum of boarding and alighting number of passengers to get average boarding and alighting time per passenger. By doing so, the extra time that any vehicle passes over the station was included. Clearance time, which is the time, spent in decelerating and accelerating the vehicle and in opening and closing the doors was determined. It was found that public transport vehicles require about 10 seconds to open and close their doors and pull in and out of a station. Thus from all this data, existing saturation level of the public transport system at every stop for buses was analyzed.The same procedure was applied for wagons.

Sample Table used for collecting data for existing saturation level (XE):

\begin{tabular}{|c|c|c|c|c|c|c|c|c|c|c|c|c|c|c|}
\hline & & Dat & for $I$ & xisting & Satura & tion leve & $(\mathbf{X}$ & B) & at $\mathrm{e}$ & ery & stop $\left(F_{c}\right.$ & C Bus & & \\
\hline DA & STO & DIRECTI & $\begin{array}{r}\text { TIME } \\
(15\end{array}$ & $\begin{array}{l}\text { TERVAL } \\
\text { inutes) }\end{array}$ & No of & $\begin{array}{l}\text { Frequency } \\
\text { (No of }\end{array}$ & & & & & $\begin{array}{c}\text { Time } \\
\text { Differenc }\end{array}$ & $\begin{array}{c}\text { Till } \\
15 \\
\text { minu }\end{array}$ & $\begin{array}{l}\text { Average } \\
\text { Ta \& Tb }\end{array}$ & Average \\
\hline & & & $\begin{array}{l}\text { Arriva } \\
\text { I Time }\end{array}$ & $\begin{array}{c}\text { Departur } \\
\text { e Time }\end{array}$ & & & $\mathbf{P a}$ & Pb & $\mathbf{P a}$ & Pb & (minutes) & $\begin{array}{l}\mathbf{P a}+\mathbf{P} \\
\mathbf{b}\end{array}$ & & \\
\hline $\begin{array}{c}\text { Mo } \\
\text { n } \\
\text { Tue } \\
\text { s } \\
\text { We } \\
\text { d }\end{array}$ & & $\begin{array}{c}\text { Gora } \\
\text { Qabristan } \\
\text { to Phase- } \\
3\end{array}$ & & & & & & & & & & & & \\
\hline $\begin{array}{l}\text { Ave } \\
\mathrm{Tb}\end{array}$ & & $\begin{array}{l}\text { alue of Fr } \\
\text { Ion-Wed }\end{array}$ & $\begin{array}{l}\text { quenc } \\
\text { or this }\end{array}$ & $\begin{array}{l}\mathrm{Pa}, \mathrm{Pb}, \\
\mathrm{op}\end{array}$ & & & & & & & & & & \\
\hline
\end{tabular}

The amount of time that any given vehicle is occupying a given stopping bay is known as the dwell time. The equation for Dwell Time is [6]:

$$
\mathrm{td}=[(\mathrm{Pb} \times \mathrm{Tb})+(\mathrm{Pa} \times \mathrm{Ta})+\mathrm{toc}] / 3600
$$

td = Dwell Time

toc $=$ Time for opening and closing the doors

$\mathrm{Pb}=$ Number of boarding passengers per bus

$\mathrm{Pa}=$ Number of alighting passengers per bus

Dwell time under existing condition was analyzed from the collected data. Finally the Saturation Levels and Dwell Times (sec) for existing public transport system were re-analyzed and comparison graphs of these two factors with the existing public transport system were plotted [Figure 02 and 03 ].

\section{Analysis \& Results}

After a detailed survey on University Road from Gora Qabristan to Phase-3 Intersectionthe stops counted were as:
1) Gora Qabristan stop
3) Tanbwaanstop
5) Arbab Road stop
2) Thahkal stop
4) Gul Hajji stop
6) Jahangir Abad stop 
7) Town Thana stop

8) KTH stop
9) Islamia College Gate 1 stop

10) Islamia College Gate 2 stop
11) Board Bazaar stop

12) Phase-3 stop

Detailed locations of these bus stops are shownin Figure 01. The existing number of bus stops at the selected 7.20 Km lengthwere found less than the recommended number of bus stops [6]. According to principles of public transport, there should be at least 2 stops per $\mathrm{Km}$ ( 3 or 4 per mile) [6].

It was found from demand analysisthat there is need for the provision of a segregated bus lane for Bus Rapid Transit (BRT) system[Table03a]. The demand of public mobility on selected corridor is 1723 passengers per hour in the direction of Gora Qabristan towards Phase-3 Intersection. In order to avoid delay under present condition, the length of alternative routes use by public transport is almost 3 times more than the University Road. Thus considering the expected demand to be 2 or 3 times more than the demand on the University Road satisfy the condition for the provision of a separate lane. The outer lane (kerb lane) was consideredsuitable for bus rapid transit system in analysis. Due to thirteen U- turns at various locations on selected corridor, the inner lane was foundnot useful for BRT. Consideringmiddle lane would either requirenew (elevated or underground) bus stops otherwise the buses will continuously interrupt the outer lane for collecting passengers. Therefore, kerb lane was selected for analysis of BRT system may be suitable in context of the present situation on university road Peshawar.

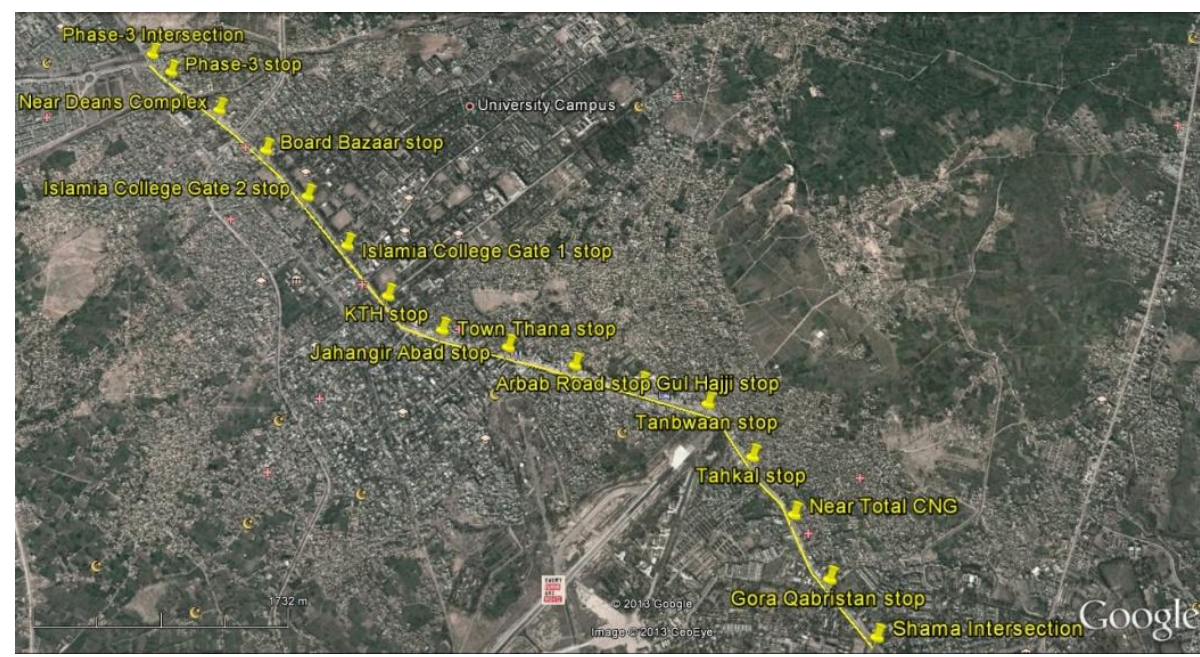

Figure01Location of stops at university Road Peshawar

Table 03(a):Demand Analysis

\begin{tabular}{|l|c|l|}
\hline \multicolumn{3}{|c|}{ Gora Qabristan towards Phase-3 Direction } \\
\hline Description & Detail & Remarks \\
\hline Pphpd (Buses) & 1007 & Existing demand for buses. \\
\hline Pphpd (Wagons) & 716 & Existing demand for wagons. \\
\hline Pphpd (A) (Buses + Wagons) & 1723 & Warrant to provide Segregated bus lane is satisfied. \\
\hline
\end{tabular}

The observed existing public transport vehicles (Buses+Wagons) were found5.1\% of the private vehicle fleet per hour. Thus for a new BRT system, 20\% projected Modal shift from private vehicles to public transport was added to the existing demand[Table02, 03] $[9,10]$. The detail is shown in the table 03 .

Table 03(b):Gora Qabristan towards Phase-3 Direction

\begin{tabular}{|l|c|l|}
\hline \multicolumn{1}{|c|}{ Description } & Detail & \multicolumn{1}{|c|}{ Remarks } \\
\hline Pphpd (Buses) & 1007 & Existing demand for buses. \\
\hline Pphpd (Wagons) & 716 & Existing demand for wagons. \\
\hline Pphpd (A) (Buses + Wagons) & 1723 & $\begin{array}{l}\text { Warrant to provide Segregated bus lane is } \\
\text { satisfied. }\end{array}$ \\
\hline Existing Frequency of Buses over stop & 20 & \\
\hline Existing Frequency of Wagons over stop & 22 & \\
\hline Private vehicles frequency per hour & 829 & \\
\hline $\begin{array}{l}\text { Percentage of Public transport vehicles (Buses+Wagons) } \\
\text { with respect to private vehicles per hour }\end{array}$ & $5.1 \%$ & $\begin{array}{l}\text { For new BRT system, 20\% Projected Modal } \\
\text { Shift from private vehicles should add. }\end{array}$ \\
\hline
\end{tabular}


The Study of Bus Rapid Transit (BRT) System at University Road Peshawar, Pakistan

\begin{tabular}{|c|c|c|}
\hline $\begin{array}{l}20 \% \text { projected private vehicles per hour to the new BRT } \\
\text { system }\end{array}$ & 166 & \\
\hline $\begin{array}{l}\text { Projected number of passengers per hour from private } \\
\text { vehicles }\end{array}$ & 332 & $\begin{array}{l}\text { Assuming average two persons per private } \\
\text { vehicle. }\end{array}$ \\
\hline Pphpd (AM) (Buses) including Modal shift & 1201 & $\begin{array}{l}\text { Pphpd (Buses) are } 58 \% \text { of the total public } \\
\text { transport passengers, thus assumed same } \\
\text { percentage of the projected number of } \\
\text { passengers towards buses. }\end{array}$ \\
\hline Pphpd (AM) (Wagons) including Modal shift & 854 & $\begin{array}{l}\text { Pphpd (Wagons) are } 42 \% \text { of the total public } \\
\text { transport passengers, thus assumed same } \\
\text { percentage of the projected number of } \\
\text { passengers towards wagons. }\end{array}$ \\
\hline Pphpd (AM) (Buses + Wagons) & 2054 & $\begin{array}{l}\text { Total proposed demand for buses and } \\
\text { wagons. }\end{array}$ \\
\hline
\end{tabular}

The saturation leveland dwell time (sec) at stops for the existing public transport system were analyzed as shown in the table 04 .

Table04Analysis (Existing Public Transport System)

\begin{tabular}{|c|c|c|c|c|c|c|c|}
\hline \multicolumn{8}{|c|}{ Gora Qabristan to Phase-3 Direction } \\
\hline For Buses: & & & & & & & \\
\hline Stops & $\begin{array}{l}\text { Frequency } \\
\text { (No of } \\
\text { Buses/hr) }\end{array}$ & 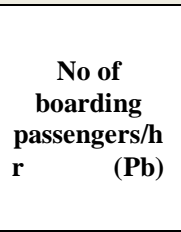 & $\begin{array}{c}\text { No of } \\
\text { alighting } \\
\text { passengers/ } \\
\text { hr }(\mathbf{P a})\end{array}$ & $\begin{array}{c}\text { Average } \\
\text { boarding \& } \\
\text { alighting time } \\
\text { per passenger } \\
\text { (Seconds/passen } \\
\text { ger) }\end{array}$ & $\begin{array}{l}\text { Saturati } \\
\text { on level } \\
\text { (XEB) }\end{array}$ & $\begin{array}{c}\text { Boardin } \\
\text { g \& } \\
\text { Alightin } \\
\text { g } \\
\text { passenge } \\
\text { rs per } \\
\text { Bus } \\
\end{array}$ & $\begin{array}{l}\text { Dwell } \\
\text { Time } \\
\text { (sec) }\end{array}$ \\
\hline Gora Qabristan & 17 & 67 & 64 & 10 & 0.43 & 8 & 81 \\
\hline Thahkal & 19 & 69 & 83 & 10 & 0.50 & 8 & 87 \\
\hline Tanbwaan & 20 & 75 & 69 & 9 & 0.41 & 7 & 66 \\
\hline Gul Hajji & 20 & 77 & 84 & 8 & 0.43 & 8 & 70 \\
\hline Arbab Road & 20 & 76 & 85 & 10 & 0.51 & 8 & 84 \\
\hline Jahangir Abad & 21 & 79 & 69 & 10 & 0.46 & 7 & 70 \\
\hline Town Thana Stop & 21 & 73 & 80 & 10 & 0.49 & 7 & 74 \\
\hline KTH Stop & 21 & 84 & 93 & 11 & 0.58 & 8 & 89 \\
\hline $\begin{array}{l}\text { Islamia College } \\
\text { Gate } 1\end{array}$ & 21 & 73 & 88 & 8 & 0.41 & 8 & 60 \\
\hline $\begin{array}{l}\text { Islamia College } \\
\text { Gate } 2\end{array}$ & 20 & 59 & 87 & 9 & 0.41 & 7 & 66 \\
\hline Board Bazaar & 21 & 93 & 113 & 12 & 0.75 & 10 & 119 \\
\hline Phase-3 & 21 & 59 & 93 & 9 & 0.45 & 7 & 68 \\
\hline AVERAGE & 20 & 74 & 84 & 10 & 0.50 & 8 & 78 \\
\hline \multicolumn{8}{|l|}{ For Wagons: } \\
\hline Stops & $\begin{array}{c}\text { Frequency } \\
\text { (No of } \\
\text { Wagons/hr } \\
\text { ) }\end{array}$ & 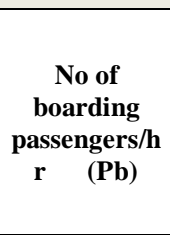 & $\begin{array}{c}\text { No of } \\
\text { alighting } \\
\text { passengers/ } \\
\text { hr }(\mathbf{P a})\end{array}$ & $\begin{array}{c}\text { Average } \\
\text { boarding \& } \\
\text { alighting time } \\
\text { per passenger } \\
\text { (Seconds/passen } \\
\text { ger) }\end{array}$ & $\begin{array}{l}\text { Saturati } \\
\text { on level } \\
\text { (XEW) }\end{array}$ & $\begin{array}{c}\text { Boardin } \\
\text { g \& } \\
\text { Alightin } \\
\text { g } \\
\text { passenge } \\
\text { rs per } \\
\text { Wagon }\end{array}$ & $\begin{array}{l}\text { Dwell } \\
\text { Time } \\
\text { (sec) }\end{array}$ \\
\hline Gora Qabristan & 24 & 44 & 25 & 19 & 0.44 & 3 & 58 \\
\hline Thahkal & 24 & 52 & 56 & 15 & 0.53 & 5 & 71 \\
\hline Tanbwaan & 24 & 60 & 60 & 10 & 0.41 & 5 & 53 \\
\hline Gul Hajji & 23 & 65 & 61 & 10 & 0.41 & 6 & 57 \\
\hline Arbab Road & 23 & 51 & 52 & 15 & 0.49 & 5 & 71 \\
\hline Jahangir Abad & 23 & 60 & 65 & 10 & 0.41 & 6 & 56 \\
\hline Town Thana Stop & 20 & 32 & 40 & 18 & 0.42 & 4 & 68 \\
\hline KTH Stop & 20 & 69 & 88 & 11 & 0.54 & 8 & 89 \\
\hline $\begin{array}{l}\text { Islamia College } \\
\text { Gate } 1\end{array}$ & 20 & 44 & 61 & 12 & 0.41 & 5 & 65 \\
\hline
\end{tabular}


The Study of Bus Rapid Transit (BRT) System at University Road Peshawar, Pakistan

\begin{tabular}{|l|c|c|c|c|c|c|c|}
\hline $\begin{array}{l}\text { Islamia College } \\
\text { Gate 2 }\end{array}$ & 19 & 24 & 61 & 15 & 0.42 & 5 & 72 \\
\hline Board Bazaar & 20 & 49 & 79 & 19 & 0.73 & 6 & 124 \\
\hline Phase-3 & 20 & 25 & 69 & 13 & 0.41 & 5 & 66 \\
\hline AVERAGE & 22 & 48 & 60 & 14 & 0.47 & 5 & 71 \\
\hline
\end{tabular}

The existing saturation level (XE) at all the stations both for buses and wagons (as in Table04) are greater than 0.4. According to 2007 BRT Planning guidelines of Institute for Transportation \& Development Policy USA, the saturation level of stations should be less than or equal to 0.40 so that to achieve an acceptable level of service[11,12]. An acceptable level of service is typically defined as the ability to achieve an average commercial speed of $25 \mathrm{Km} / \mathrm{h}$. The general assumption for achieving this level of service is a saturation of approximately 40 percent $(\mathrm{X}=0.4)$ or less [13]. Thus the existing public transport system has not the ability to achieve an acceptable level of service and result in the delays and long queues at stopping bays.

The saturation level and dwell time (sec) at the stops for the proposed BRT system werere-analyzed as shown in the table 05 and in Figures 02 and 03.

Table05Analysis (Bus Rapid Transit System)

\begin{tabular}{|c|c|c|c|c|c|c|c|}
\hline \multicolumn{8}{|c|}{ Gora Qabristan to Phase-3 Direction } \\
\hline \multicolumn{8}{|l|}{ For Buses: } \\
\hline Stops & $\begin{array}{l}\text { Frequency } \\
\text { (No of } \\
\text { Buses/hour } \\
\text { ) }\end{array}$ & $\begin{array}{c}\text { No of } \\
\text { boarding } \\
\text { passengers/h } \\
\text { our } \\
(\mathrm{Pb})\end{array}$ & $\begin{array}{c}\text { No of } \\
\text { alighting } \\
\text { passengers/h } \\
\text { our }(\mathbf{P a})\end{array}$ & $\begin{array}{c}\text { Average } \\
\text { boarding \& } \\
\text { alighting time } \\
\text { per passenger } \\
\text { (Seconds/passe } \\
\text { nger) }\end{array}$ & $\begin{array}{l}\text { Satura } \\
\text { tion } \\
\text { level } \\
\text { (XPB) }\end{array}$ & $\begin{array}{c}\text { Boardin } \\
\text { g \& } \\
\text { Alightin } \\
\text { g } \\
\text { passenge } \\
\text { rs per } \\
\text { Bus } \\
\end{array}$ & $\begin{array}{l}\text { Dwel } \\
\text { l } \\
\text { Time } \\
\text { (sec) }\end{array}$ \\
\hline Gora Qabristan & 35 & 123 & 48 & 3 & 0.24 & 5 & 18 \\
\hline Near Total CNG & 25 & 47 & 45 & 3 & 0.15 & 4 & 14 \\
\hline Thahkal & 25 & 69 & 79 & 3 & 0.19 & 6 & 21 \\
\hline Tanbwaan & 25 & 104 & 99 & 3 & 0.24 & 8 & 27 \\
\hline Gul Hajji & 35 & 154 & 161 & 3 & 0.36 & 9 & 30 \\
\hline Arbab Road & 25 & 106 & 115 & 3 & 0.25 & 9 & 29 \\
\hline Jahangir Abad & 25 & 107 & 98 & 3 & 0.24 & 8 & 28 \\
\hline Town Thana Stop & 25 & 102 & 108 & 3 & 0.24 & 8 & 28 \\
\hline KTH Stop & 35 & 167 & 177 & 3 & 0.38 & 10 & 32 \\
\hline $\begin{array}{l}\text { Islamia College } \\
\text { Gate } 1\end{array}$ & 25 & 100 & 115 & 3 & 0.25 & 9 & 29 \\
\hline $\begin{array}{l}\text { Islamia College } \\
\text { Gate } 2\end{array}$ & 25 & 80 & 108 & 3 & 0.23 & 8 & 26 \\
\hline Board Bazaar & 25 & 97 & 112 & 3 & 0.24 & 8 & 28 \\
\hline $\begin{array}{l}\text { Near Deans } \\
\text { Complex }\end{array}$ & 25 & 48 & 66 & 3 & 0.17 & 5 & 17 \\
\hline Phase-3 & 35 & 48 & 138 & 3 & 0.25 & 5 & 19 \\
\hline AVERAGE & 28 & 97 & 105 & 3 & 0.25 & 7 & 25 \\
\hline \multicolumn{8}{|l|}{ For Wagons: } \\
\hline Stops & $\begin{array}{l}\text { Frequency } \\
\text { (No of } \\
\text { Wagons/ho } \\
\text { ur) }\end{array}$ & $\begin{array}{c}\text { No of } \\
\text { boarding } \\
\text { passengers/h } \\
\text { our } \\
\text { (Pb) }\end{array}$ & $\begin{array}{c}\text { No of } \\
\text { alighting } \\
\text { passengers/h } \\
\text { our }(\mathbf{P a})\end{array}$ & $\begin{array}{c}\text { Average } \\
\text { boarding \& } \\
\text { alighting time } \\
\text { per passenger } \\
\text { (Seconds/passe } \\
\text { nger) }\end{array}$ & $\begin{array}{c}\text { Saturati } \\
\text { on level } \\
(\mathrm{XPW})\end{array}$ & $\begin{array}{l}\text { Boardin } \\
\text { g \& } \\
\text { Alightin } \\
\text { g } \\
\text { passeng } \\
\text { ers per } \\
\text { Wagon } \\
\end{array}$ & $\begin{array}{c}\text { Dwe } \\
\text { ll } \\
\text { Tim } \\
\text { e } \\
\text { (sec } \\
\text { ) }\end{array}$ \\
\hline Gora Qabristan & 30 & 46 & 19 & 3 & 0.14 & 2 & 11 \\
\hline Near Total CNG & 30 & 30 & 27 & 3 & 0.13 & 2 & 11 \\
\hline Thahkal & 30 & 44 & 47 & 3 & 0.16 & 3 & 14 \\
\hline Tanbwaan & 30 & 68 & 68 & 3 & 0.20 & 5 & 19 \\
\hline Gul Hajji & 30 & 79 & 75 & 3 & 0.21 & 5 & 20 \\
\hline Arbab Road & 30 & 65 & 67 & 3 & 0.19 & 4 & 18 \\
\hline Jahangir Abad & 30 & 64 & 69 & 3 & 0.19 & 4 & 18 \\
\hline Town Thana Stop & 30 & 41 & 49 & 3 & 0.16 & 3 & 14 \\
\hline KTH Stop & 30 & 87 & 105 & 3 & 0.24 & 6 & 24 \\
\hline
\end{tabular}


The Study of Bus Rapid Transit (BRT) System at University Road Peshawar, Pakistan

\begin{tabular}{|l|c|c|c|c|c|c|c|}
$\begin{array}{l}\text { Islamia College } \\
\text { Gate 1 }\end{array}$ & 30 & 48 & 65 & 3 & 0.18 & 4 & 16 \\
\hline $\begin{array}{l}\text { Islamia College } \\
\text { Gate 2 }\end{array}$ & 30 & 33 & 71 & 3 & 0.17 & 3 & 15 \\
\hline Board Bazaar & 30 & 45 & 67 & 3 & 0.18 & 4 & 16 \\
\hline $\begin{array}{l}\text { Near Deans } \\
\text { Complex }\end{array}$ & 30 & 24 & 42 & 3 & 0.14 & 2 & 12 \\
\hline Phase-3 & 30 & 27 & 59 & 3 & 0.15 & 3 & 14 \\
\hline AVERAGE & 30 & 50 & 59 & 3 & $\mathbf{0 . 1 7}$ & 4 & $\mathbf{1 6}$ \\
\hline
\end{tabular}

The saturation levels of the stations along the corridor calculated for the proposed BRT system were not more than 0.4 both for buses and wagons. Thus the proposed BRT system will have the ability to achieve an average commercial speed of $25 \mathrm{Km} / \mathrm{h}$ with adequate capacity that may handle the existing as well as expected modal shift demand with higher frequency than the existing condition. This will also minimize the passengers waiting times at the stops.

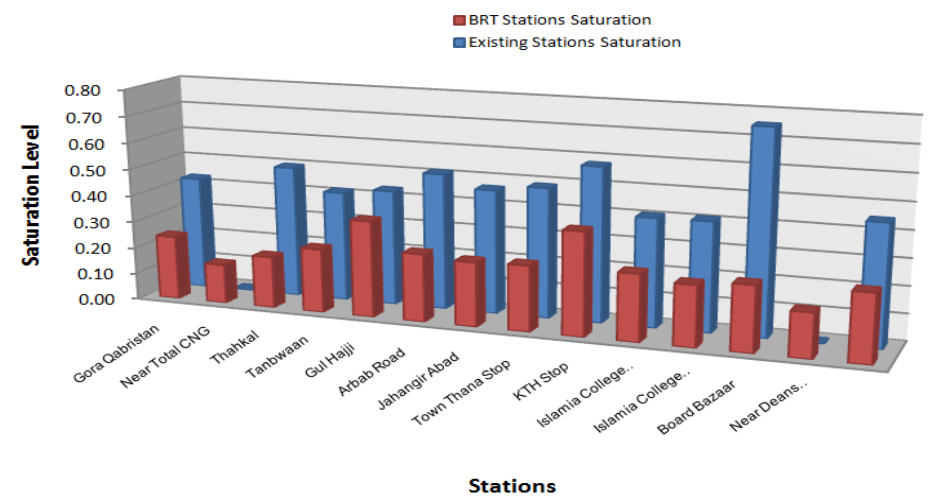

Figure02 Comparison stations' saturation levels

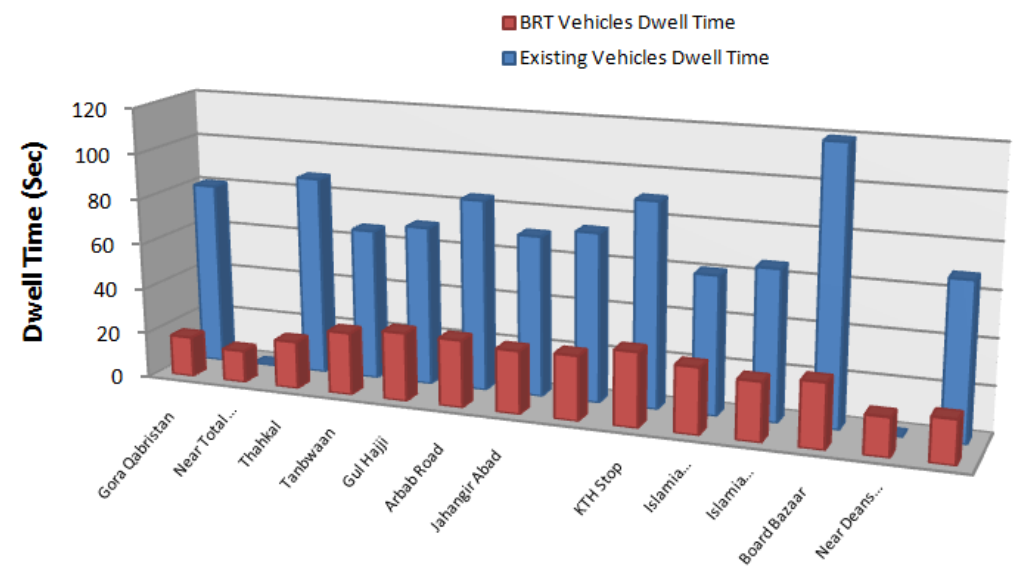

Figure 03 Comparison of dwell times

\section{Micro-simulation in S-Paramics}

Micro simulation a computer modeling system which represents the behavior of individual vehicles and their drivers in a road network was applied to the data[14]. Vehicles were modeled to observe the rules of the road and to interact with other road users through simple rules[Figure 4]. The cumulative effect of modeling individual vehicles realistically represents road traffic flow on a physical road network. The technique was applied to present the output as a real-time visual display. University road that was manually analyzed was also modeled in S-Paramics [Figure 5]. Out of three lanes in each direction, the kerb (outer lane) was usedfor simulation of BRT. This public transport model simulates the public transport system and is mainly use to investigate the flow of buses throughout the entire system. 


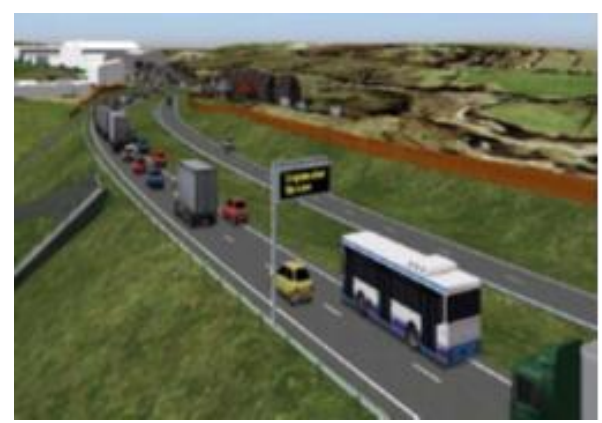

Figure 04 modeling in S Paramics

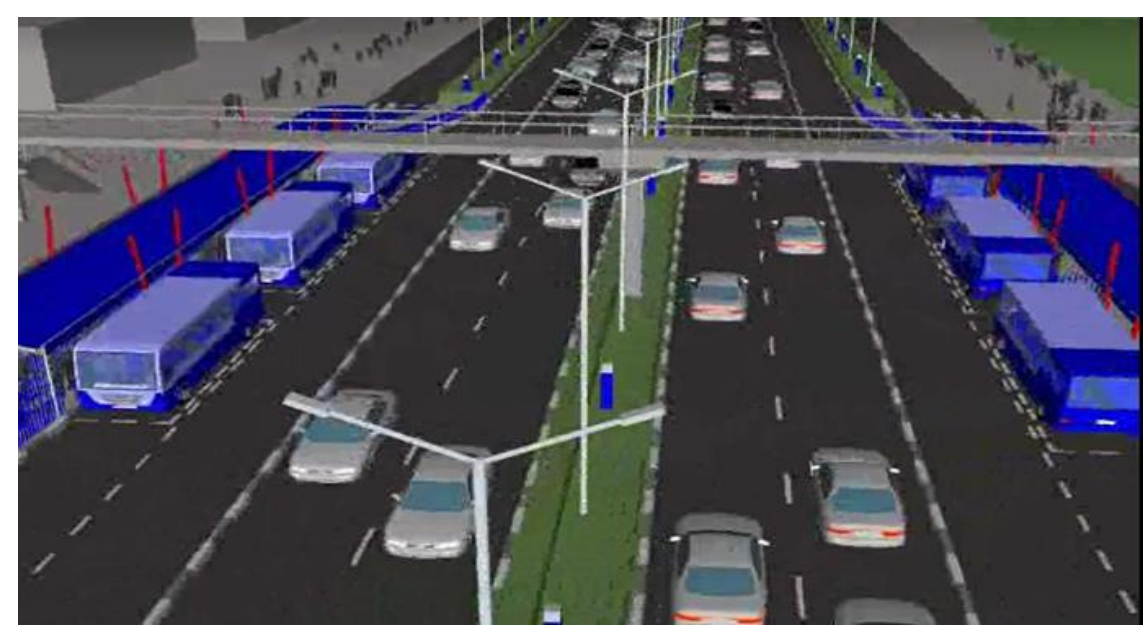

Figure 05BRT Simulation in S-Paramics

\section{Conclusion}

- Existing stops Dwell Times and Saturation levels are higher than the recommended values to achieve an acceptable level of service.

- Scheduling of the trips is very unpredictable in existing public transport system.

- Due to randomness (Undisciplined stopping for boarding and alighting) and improper management, the existing public transport system has not the ability to handle the demand comfortably on the corridor.

- There is the need for the provision of segregated bus lane for Bus Rapid Transit (BRT) system on the studied corridor.

- BRT Simulation Model shows that the proposed system will have the ability to achieve an acceptable level of service with adequate capacity and frequent service.

\section{References}

[1]. Bus Rapid Transit Planning Guide 2007 by Institute for Transportation and Development Policy (ITDP).

[2]. Characteristics of Bus Rapid Transit for Decision-Making, Project No: FTA-VA-26-7222-2004.1, August 2004 by Federal Transit and Administration United States Department of Transportation.

[3]. A Preliminary Feasibility Study of Bus Rapid Transit System in Dhaka by S. M. Sohel Mahmud and Mohammad IbnaAnwar, May 2007.

[4]. Hossain, Moazzem. 2006. The issues and realities of BRT planning initiatives in Developing Asian cities. Journal of Public Transportation BRT Special Edition.

[5]. Institute for Global Environmental Strategies (IGES). 2007. Best Practice Environmental Policy in Asia and the Pacific. International Review for Environmental Strategies Special Edition.

[6]. Transportation Engineering 2nd edition by James H. Banks.

[7]. Broken Arrow to Tulsa Mass Transit Feasibility Study by Lonnie E. Blaydes Consulting, April 2007.

[8]. Pre-Feasibility Study for Bus Rapid Transit Hyderabad, Andhra Pradesh by the Institute for Transportation and Development Policy, March, 2005.

[9]. Bus Rapid Transit Ridership Analysis by U.S. Department of Transportation Federal Transit Administration, June 2005.

[10]. Harsanto, Damar. 2003. City urged to involve public in busway plan. The Jakarta Post, February 27.

[11]. Hook, Walter, Karl Fjellstrom, and Oscar Edmundo Diaz. 2006. Options for Financing Bus Rapid Transit in China.

[12]. Junaidi, Ahmad. 2002. After fanfare, busway project now postponed. The Jakarta Post, October 10.

[13]. Sutomo, Heru. 2006. Bus rapid transit in Jakarta: evaluating the factors that impede or facilitate In Comission Paper submitted to the Institute for Global Environmental Strategies: Center for Transportation Studies, GadjahMada University

[14]. S-Paramics Principles by ParamicsMicrosimulation, SIAS Limited 